\title{
Earthquake Vulnerability Assessment and Housing in districts of Himanchal Pradesh and Uttrakhand
}

\section{Kritika Bora}

\section{Introduction}

In the past few decades India has witnessed some of the most devastating earthquakes. Earthquakes usually occur with no warning but a series of frequent shocking waves followed by a major earthquake. The impact of an earthquake is sudden. In India, like other countries of the world the earthquake prone areas are well defined and have divided into different risk zones according to the potential threat they possess. Himalayan region have been a zone of active tectonics because of its recent formation and continuous subduction of the Indian plate.

Himanchal Pradesh and Uttrakhand, two states of Central Himalayas possess potential threat from earthquake because of their geo-physical location and fall in seismic zone $4 \& 5$ which points towards high to very high damage risk zone (Fig $1 \& 2$ ). The presence of MBT (Main Boundary Thurst) \& MCT(Main Central Thrust) over these states results in frequent release of energy causing ground shakes on a regular basis. The presentwork explains the current housing vulnerability status of two district of Himanchal Pradesh i.e. Chamba\&Kangra and Uttarkashi District of Uttrakhand.

Fig 1.Epicentral and Earthquake Hazard Map of Himanchal Pradesh.

*(Source BMTPC Vulnerability Atlas of Himachal Pradesh)

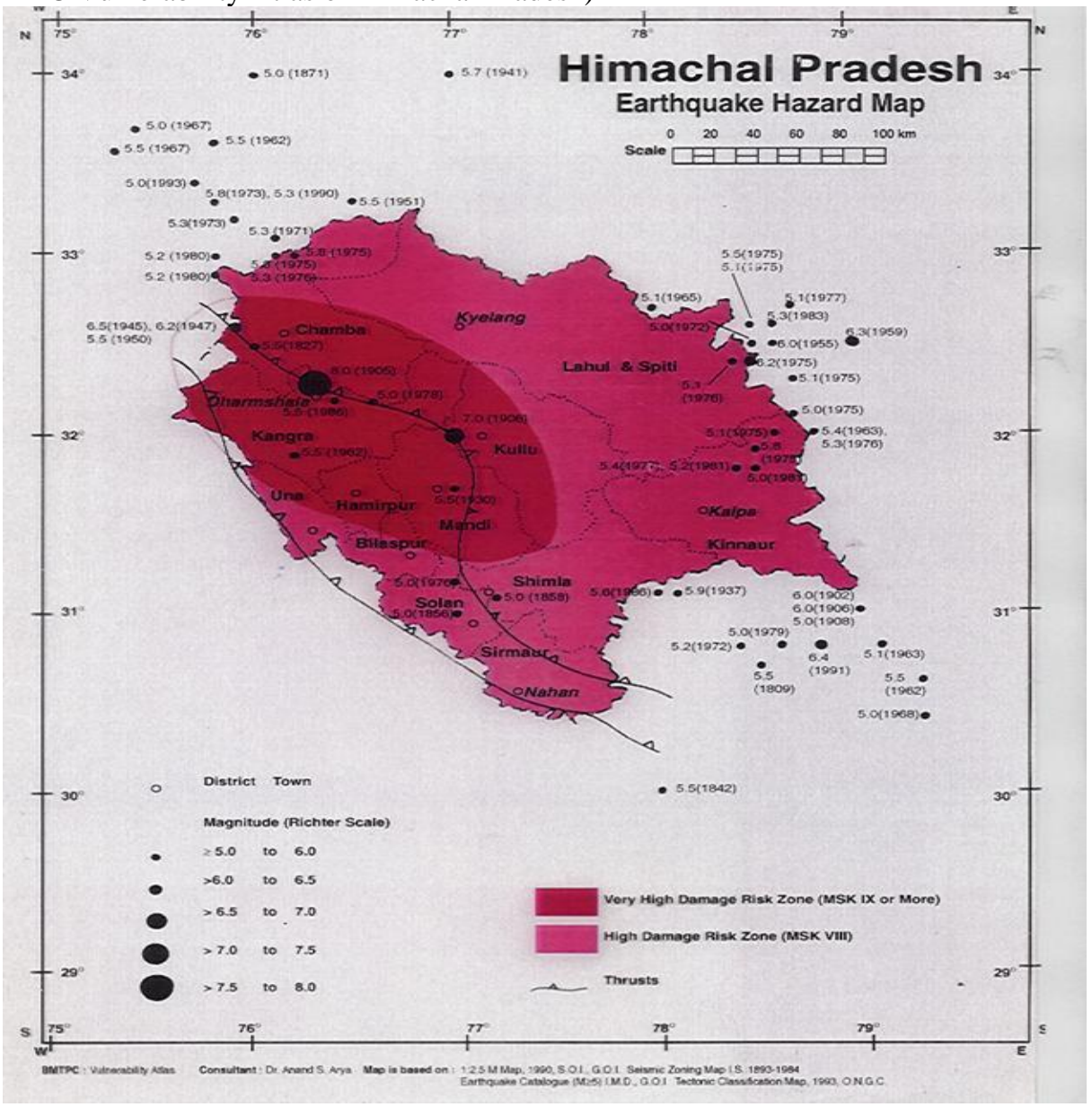


Fig2: Map showing Uttrakhand Earthquake Zones

*Source: UNDP, India

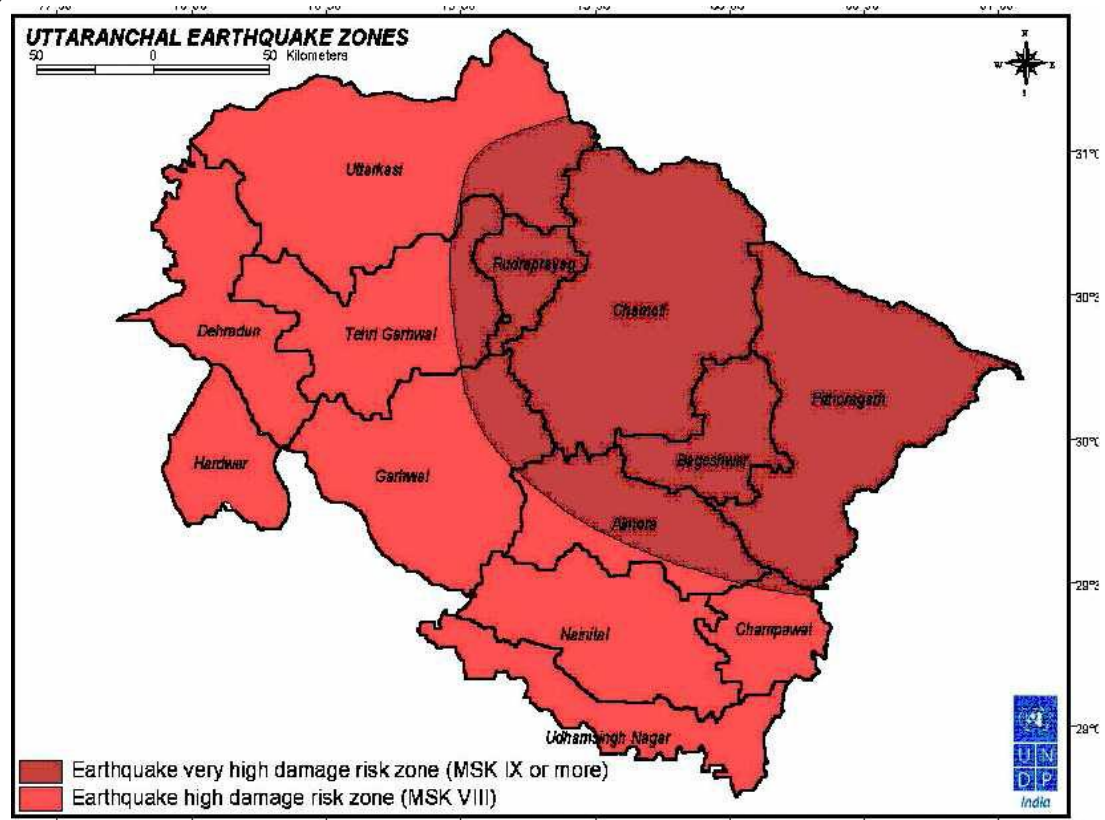

Chamba district lies in seismic zone 5 whereas some parts of Kangralies in both seismic zone $4 \& 5$. Similarly Uttarkashi share a seismic zonation of both $4 \& 5$. All three districts hold a history when it comes to major earthquake events.

- April 4, 1905 in Kangra, an earthquake of 7.8 magnitude 20,000 people killed and 53,000 domestic animals in perished while 1 lakh houses were destroyed. Economic cost of recovery was estimated to be Rs 29 lakh during that time.

- March 24, 1995 in Chamba, an earthquake of 4.9 magnitude had left over 79percent houses with cracks.

- October 20, 1991 earthquake of 6.8 magnitude in Uttarkashikilled 786 people dead and more than 5000 injured. 42,400 houses were damaged.

The above events of earthquake demonstrate the intensity of damage to life and property these districts possess. Because of the large scale impact of earthquake it causes great damage to not only life but economic and social structure also. The impact of these shocking events can still be seen over the houses of these districts. The old construction practices and local material used for the buildings makes the houses here more vulnerable to earthquakes. Therefore the identification of the building types and their categorization on the basis of building type and material used (Table 1) is essential to mitigate the impact of such earthquakes over these areas.

Table1: Categorization of Building Material and House type

*Source: Vulnerability Atlas of India, 1997

\begin{tabular}{|c|c|c|c|}
\hline Code & Building Material Type & Wall Type & Roof Type \\
\hline \multirow[t]{4}{*}{ A } & \multirow[t]{4}{*}{$\begin{array}{l}\text { Building in field stone, rural structures, unburnt } \\
\text { brick houses, clay houses }\end{array}$} & A1:Mud Wall & $\begin{array}{l}\text { All roof } \\
\text { sloping }\end{array}$ \\
\hline & & A2: Unburned Brick Wall & (a)Sloping roof \\
\hline & & \multirow[t]{2}{*}{ A3: Stone Wall } & (a) Sloping roof \\
\hline & & & (b) Flat roof \\
\hline \multirow[t]{4}{*}{$\mathrm{C}$} & \multirow{4}{*}{$\begin{array}{l}\text { Reinforced building, well built wooden } \\
\text { structures }\end{array}$} & \multirow[t]{2}{*}{ C1: concrete Wall } & (a) Sloping roof \\
\hline & & & (b) Flat roof \\
\hline & & C2: Wood Wall & All roof \\
\hline & & C3: Ekra Wall & All roof \\
\hline $\mathrm{X}$ & Other type of houses & $\mathrm{X} 1$ : GI and other material sheet & All roof \\
\hline
\end{tabular}


Fig 3: Status of Building According to Building Material Type

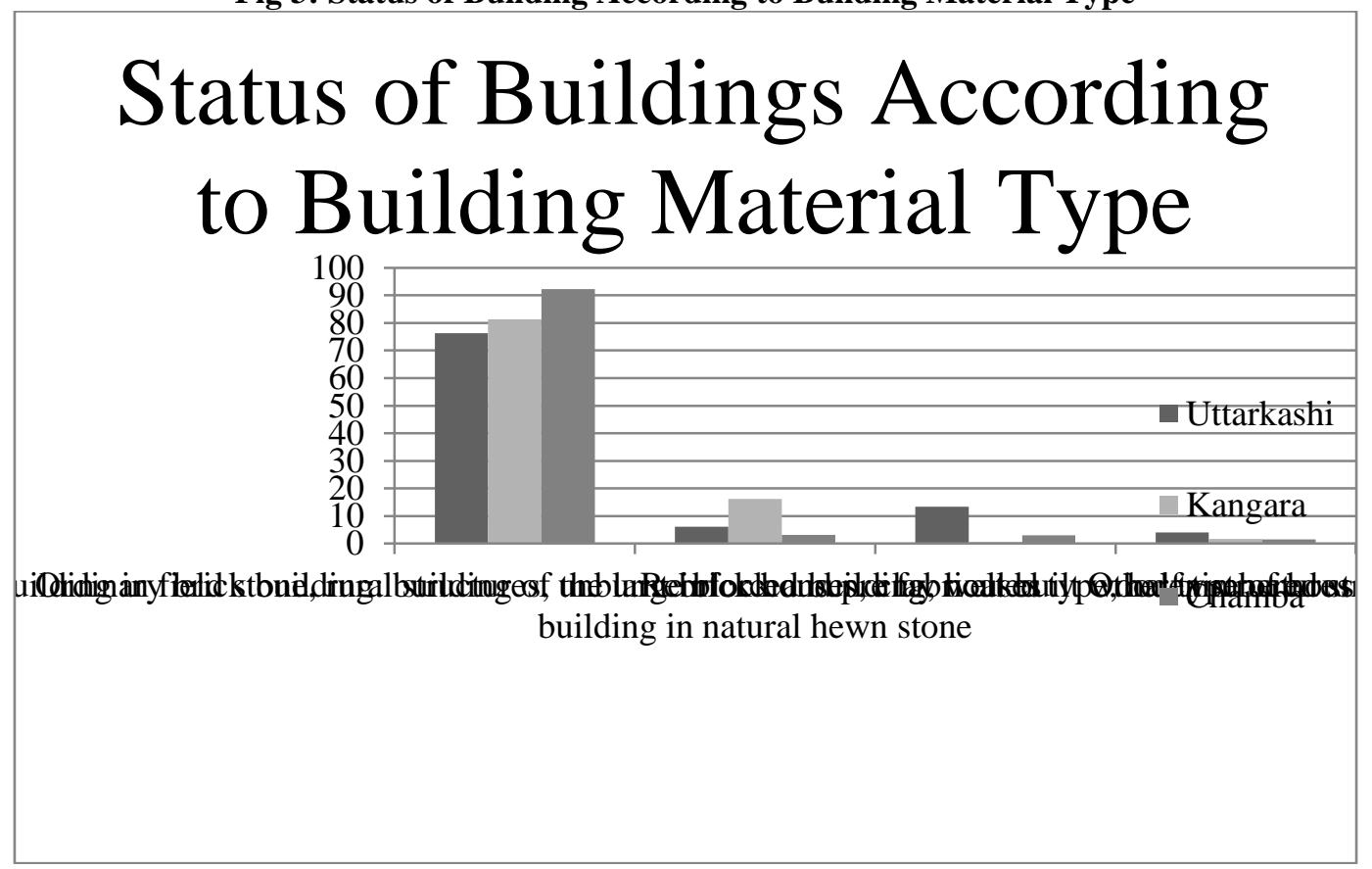

Categories of Housing Vulnerability to Earthquake (Fig 3)

A: Buildings in field- stone, rural structure, unburnt brick houses, clay houses

A1: Mud Wall

(a) All roofs sloping: Houses in Very High and high level of risk.

A2: Unburned brick wall

(a) Sloping roof: Houses in very high and high level of risks.

(b) Flat roof: Houses in very high to high level of risks.

A3: Stone wall

(a) Sloping roof: Houses in Very high to high level of risks.

(b) Flat roof: Houses in very high to high level of risks.

B: Ordinary brick building, buildings of large blocks and pre fabricated type, half- timbered structures, building in natural hewn stone of houses.

(a) Sloping roof: Houses here are in high to medium level of risks.

(b) Flat roof: houses in high to medium level of risks.

C: Reinforced building, well built, wooden structures of houses.

C1: Concrete wall

(a) Sloping roof: Houses in this category are in medium to low level of risks.

(b) Flat roof: Houses with medium to low level of risks.

C2: Wood wall (All roofs): Houses in medium to low level of risks.

C3: Ekra Wall (All roofs): Houses in medium to low level of risks.

$\mathbf{X}$ : Others

X1: GI and other metal sheet (All roofs) Houses in medium to very low level of risks.

X2: Bamboo, Thatch, Grass, level etc. (All roofs) Houses in medium to very low level of risks.

*Very High Risk: > magnitude 9

*High: > magnitude 8

*Medium: >magnitu de7

The following table shows the categorization of building type and material used in these areas. 
Table2: Percentage of houses falling in the above category

*Source: Vulnerability Atlas of India, 1997

\begin{tabular}{|c|c|c|c|c|}
\hline \multicolumn{2}{|c|}{ CODES } & \multirow{2}{*}{$\begin{array}{c}\text { UTTARKASHI } \\
\begin{array}{c}\text { 15.2percent } \geq \text { ix 84.8percent } \\
\text { viii }\end{array} \\
\mathbf{7 6 . 2 5 p e r c e n t ~ o f ~ h o u s e s ~}\end{array}$} & \multirow{2}{*}{$\begin{array}{c}\text { KANGRA } \\
\begin{array}{c}\text { 98.6percent } \geq \text { ix } 1.4 \text { percent } \\
\text { viii }\end{array} \\
\text { 81.37percent of houses }\end{array}$} & \multirow{2}{*}{\begin{tabular}{|c|} 
CHAMBA \\
63.2percent $\geq$ ix \\
36.8percent viii \\
92.25percent of houses
\end{tabular}} \\
\hline $\mathbf{A}$ & & & & \\
\hline \multirow[t]{2}{*}{$\overline{\mathrm{A} 1}$} & (a) & 0.34 in $\mathrm{VH} \& \mathrm{H}$ & 6.03 in $\mathrm{VH} \& \mathrm{H}$ & 1.60 in $\mathrm{VH} \& \mathrm{H}$ \\
\hline & (b) & - & - & - \\
\hline \multirow[t]{2}{*}{$\mathrm{A} 2$} & (a) & 0.23 in $\mathrm{VH} \& \mathrm{H}$ & 69.40 in $\mathrm{VH} \& \mathrm{H}$ & 6.32 in $\mathrm{VH} \& \mathrm{H}$ \\
\hline & (b) & 0.10 in $\mathrm{VH} \& \mathrm{H}$ & 0.17 in $\mathrm{VH} \& \mathrm{H}$ & 0.03 in $\mathrm{VH} \& \mathrm{H}$ \\
\hline \multirow[t]{2}{*}{ A3 } & (a) & 48.32 in $\mathrm{VH} \& \mathrm{H}$ & 4.83 in $\mathrm{VH} \& \mathrm{H}$ & 81.57 in $\mathrm{VH} \& \mathrm{H}$ \\
\hline & (b) & 27.27 in $\mathrm{VH} \& \mathrm{H}$ & 0.94 in $\mathrm{VH} \& \mathrm{H}$ & 2.73 in $\mathrm{VH} \& \mathrm{H}$ \\
\hline \multirow[t]{3}{*}{ B } & & 6.19percent of houses & 16.19percent of houses & 3.25percent of houses \\
\hline & (a) & 1.54 in $\mathrm{H} \& \mathrm{M}$ & 5.81 in $\mathrm{H} \& \mathrm{M}$ & 1.82 in $\mathrm{H} \& \mathrm{M}$ \\
\hline & (b) & 4.66 in $\mathrm{H} \& \mathrm{M}$ & 10.38 in $\mathrm{H} \& \mathrm{M}$ & 1.43 In H \& M \\
\hline $\mathbf{C}$ & & 13.42percent of houses & 0.72percent of houses & 3.03percent of houses \\
\hline \multirow[t]{2}{*}{$\mathrm{C} 1$} & (a) & 1.28 in $\mathrm{M} \& \mathrm{~L}$ & 0.08 in $\mathrm{M} \& \mathrm{~L}$ & 1.20 in $\mathrm{M} \& \mathrm{~L}$ \\
\hline & (b) & 2.60 in $\mathrm{M} \& \mathrm{~L}$ & 0.15 in $M \& L$ & 0.26 in $\mathrm{M} \& \mathrm{~L}$ \\
\hline $\mathrm{C} 2$ & & 9.11 in $\mathrm{M} \& \mathrm{~L}$ & 0.49 in $\mathrm{M} \& \mathrm{~L}$ & 1.57 in $\mathrm{M} \& \mathrm{~L}$ \\
\hline $\mathrm{C} 3$ & & 0.43 in $\mathrm{M} \& \mathrm{~L}$ & 0.01 In M \& L & 0.00 in $\mathrm{M} \& \mathrm{~L}$ \\
\hline $\mathbf{X}$ & & 4.14percent of houses & 1.72percent of houses & 1.47percent of houses \\
\hline $\mathrm{X} 1$ & & 1.36 in $\mathrm{M} \& \mathrm{VL}$ & 0.12 in $M \& V L$ & 1.31 in $\mathrm{M} \& \mathrm{VL}$ \\
\hline $\mathrm{X} 2$ & & 2.78 in $\mathrm{M} \& \mathrm{VL}$ & 1.72 in $M \& V L$ & 0.16 in M \& VL \\
\hline
\end{tabular}

*VH: Very High

*H: High

*M: Moderate

*VL: Very Low

From the table we conclude that most of the houses in these areas fall in the category of very high damage risk with poor building material and this make the houses more vulnerable to earthquakes. 76.25percent in Uttarkashi, 81.37percent in Kangra and 92.25percent of the houses in Chamba comes in A category where simple rural structure, mud and clay houses with unburned bricks dominates, makes it very prone to earthquakes. Following this category B include 6.19percent in Uttarkashi, 16.19percent in Kangra, and 3.25 percent of the houses in Chamba. This category include buildings made out of large blocks, half timbered, building in natural hewn stones which are comparatively less prone to earthquake than A.Category Cconsist a proportion of 13.42percent in Uttarkashi, 0.72percent in Kangra, 3.03percent of the houses in Chamba. This category uses partial engineering and therefore is considered earthquake resistant but include a small share of housing over these areas which clearly indicate the traditional building practices and knowledge and use of local material.

\section{Housing Pattern}

Talking of thisUttarkashi district, we can see from the pie diagram below that 76.25 percent of the houses belong to the A category (very high damage risk) where houses are pre dominantly made of unburned bricks, clay houses with mud, stone and unburned brick walls, 13.42percent of the houses to the B category where houses are made out of large blocks, half timbered structures. Only 6.19percent (medium to low risk) are reinforced buildings, well built with wooden, ekra, and concrete wall. Lastly 4.14percent of the houses belong to the category made of grass and bamboo thatch. 
Fig 4: Building Type in Uttarkashi of Uttrakhand

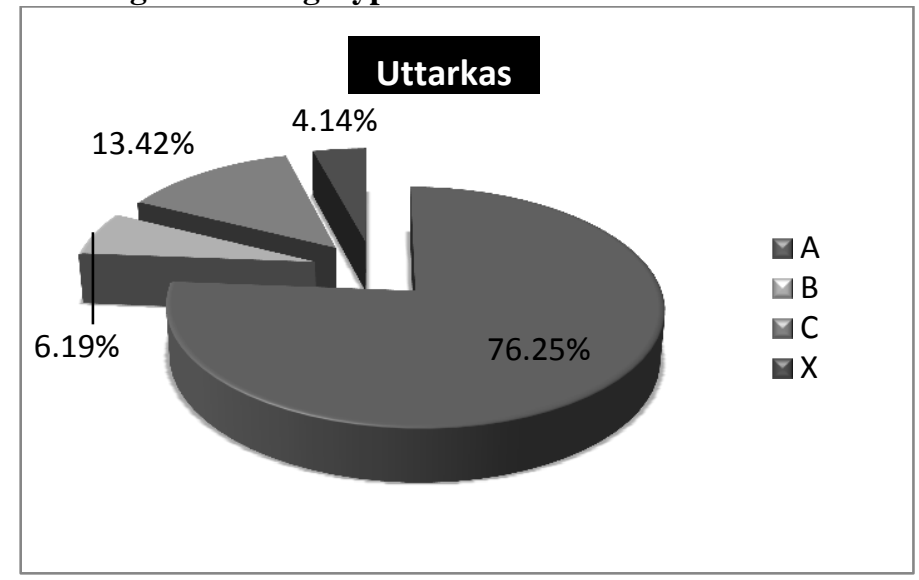

Contributing 98.6percent of the area towards seismic zone 5 Kangra district like the other areas of Himalaya has high rural population and the condition and status of houses is no different. 81.37percent of the houses are made by local materials mud and a stone wall with unburned bricks used and therefore has very high potential of damage to life and property. Also this district has a very high density of population (233). 16.19percent of the houses belong to B category (Fig 5) which are ordinary brick building are highly vulnerable to earthquake. Only 0.72percentare reinforced buildings which serve medium to low risk of earthquake. Whereas 1.72percent of the structures belong to the category of others.

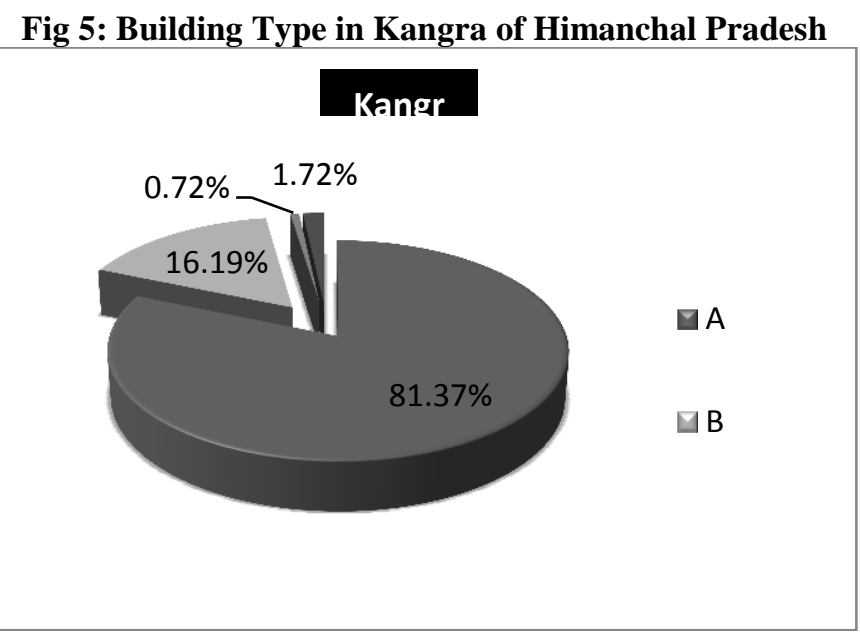

Like Uttarkashi and Kangra, district Chamba also has highest percentage of houses in A category 92.25percent with very high damage risk. Whereas 3.25 percent in B category. Unlike district Kangra here 3.03percent of the buildings fall in $\mathrm{C}$ category of reinforced buildings which perform medium to low to any earthquake incidence. 1.47percent of the structures fall in X category (Fig 6).

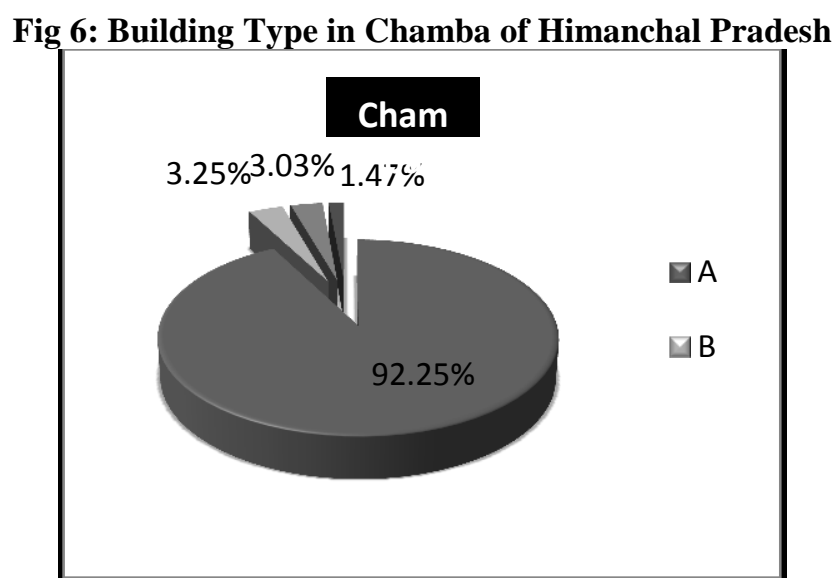




\section{Risk Scenario}

The entire Himalaya region is prone to high seismic activity or earthquakes. There have been many earthquakes recorded in this region in the past. There are 250 earthquakes of Magnitude 4.0 and more including more than 60 with Magnitude 5.0 or more, which have rocked the state of HP and adjoining areas of J\&K or UP in the last about 90 years.

Himanchal Pradesh and Uttrakhand also share a rich past in earthquakes as discussed earlier. 15.2percent of the area of Uttarkashi falls under Very High Damage Risk Zone, where as 98.6percent and 63.2percent of the area of District Kangra and Chamba respectively constitute Very High Damage Risk Zone. A very large portion of area of district Uttarkashi i.e., 84.8percent comes under High Damage Risk Zone. Unlike Uttarkashi only 1.4percent of Kangra (Fig: 8) and 36.8percent area of Chamba (Fig: 9) falls in the category of High Damage Risk Zone.

A very large portion of area of the districts of Himanchal Pradesh is prone to Very high damage which means these place possess a great threat from a seismic activity whereas on the other hand Uttarkashi consist less area in very high damage risk zone and larger in High Damage Risk Zone.

Fig 7: Risk Status of Uttarkashi District of Uttrakhand

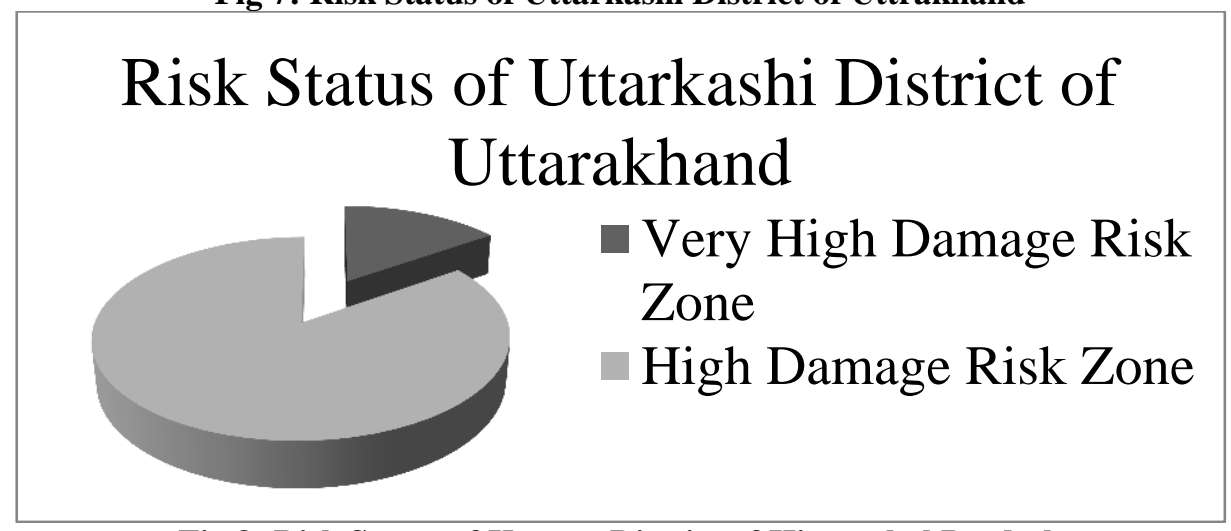

Fig 8: Risk Status of Kangra District of Himanchal Pradesh

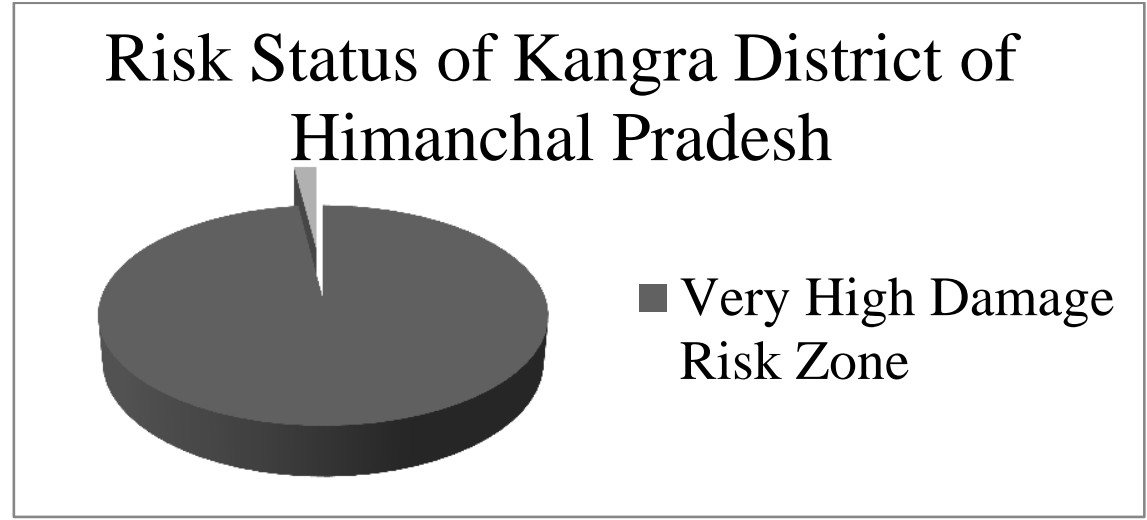

Fig 9: Risk Status of Chamba District of Himanchal Pradesh

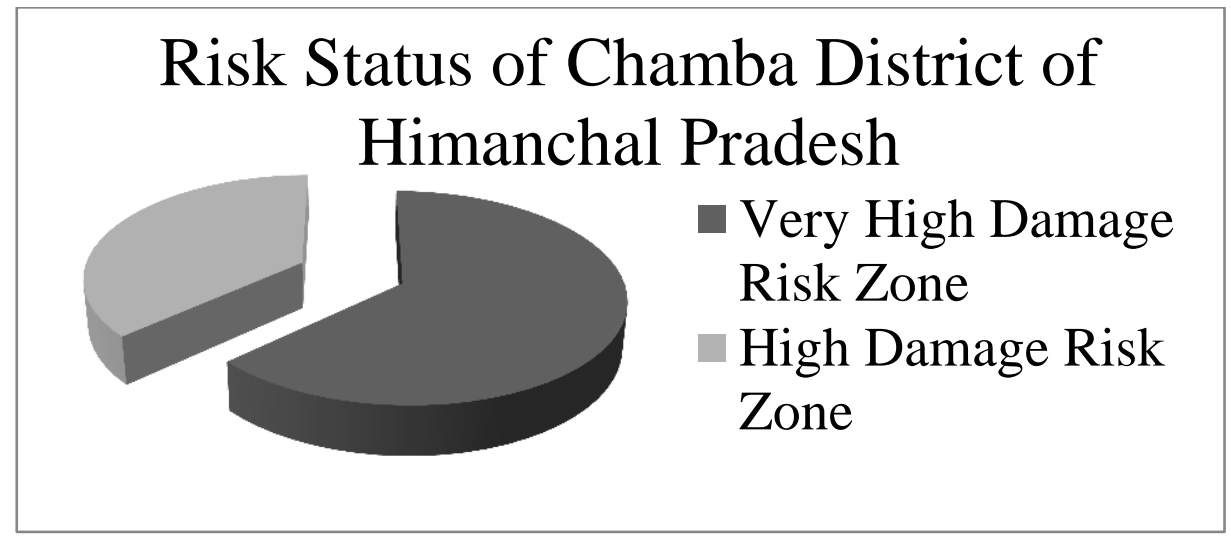


As a widely accepted fact that "Earthquake does not kill people but the buildings do" we know the overwhelming relevance of this fact. Majority of deaths and injuries in earthquake incidence occur because of the collision and collapse of buildings and other human made structures resulting in the loss of lives, property and social disruption. As mentioned earlier the entire Himalayan region falls in the category of zone $4 \& 5$ in seismic intensity because of the continuous threshing of Indian and Eurasian plate there is an urgent need to assess the buildings on vulnerability of earthquake. Vulnerability Atlas of India states that there are about 11 million seismically vulnerable houses in seismic zone 5 and corresponding figures for zone 4 is 50 million. There is unprecedented threat to over 80 million houses if earthquake strikes.

The risk assessment involves evaluation of seismic hazard, vulnerability of structure, exposure and finally loss estimation.

Studies of earthquake damage shows that some buildings tend to be more vulnerable than others as this depends on the technique and material used in construction. Reinforced buildings, well built wooden structures with concrete and wooden wall are less prone to earthquake in comparison to buildings that are made out of unburnt bricks, stone wall, large blocks, pre fabricated type, and half timbered structures. But the innovation of semi engineered and engineered techniques in construction in India have still not widened its scope. When we talk of the districts Uttarkashi, Chamba and Kangra more than 92percent of its population resides in rural areas where local materials and traditional techniques are still used in construction practices.

Table 3: Demographic structure (2011)

\begin{tabular}{|l|l|l|l|l|l|l|}
\hline Districts & $\begin{array}{l}\text { Total } \\
\text { population }\end{array}$ & $\begin{array}{l}\text { Density } \\
\text { of } \\
\text { populati } \\
\text { on }\end{array}$ & $\begin{array}{l}\text { Total } \\
\text { rural } \\
\text { population }\end{array}$ & $\begin{array}{l}\text { percent } \\
\text { of rural } \\
\text { populati } \\
\text { on }\end{array}$ & $\begin{array}{l}\text { Total urban } \\
\text { population }\end{array}$ & $\begin{array}{l}\text { Percentof } \\
\text { urban } \\
\text { populatio } \\
\text { n }\end{array}$ \\
\hline $\begin{array}{l}\text { Uttarkash } \\
\text { i }\end{array}$ & 330,086 & $\begin{array}{l}41 \text { per./sq. } \\
\mathrm{kms}\end{array}$ & 305,781 & 92.64 & 24,305 & 7.36 \\
\hline Kangra & $1,510,075$ & $\begin{array}{l}233 \mathrm{per} / \mathrm{s} \\
\text { q.kms }\end{array}$ & $1,423,794$ & 94.29 & 86,281 & 5.71 \\
\hline Chamba & 519,080 & $\begin{array}{l}80 \mathrm{per} . / \mathrm{sq} . \\
\mathrm{kms}\end{array}$ & 482,972 & 93.04 & 36,108 & 6.96 \\
\hline
\end{tabular}

*Source: www.census2011.co.in

Considering the demographic data (Table 3), we gather that, the population of all these districts is pre dominantly rural and therefore the housing pattern tends to be rural and made out of simple construction techniques and material.The density of population in district $\operatorname{Kangra(233)}$ and district $\mathrm{Chamba(80)}$ is comparatively higher than Uttarkashi(40). The risk of earthquake is almost equal in these districts but the potential loss is higher in Kangra and Chamba because of high density of population.

\section{References}

[1]. Vulnerability Atlas of India Earthquake, Windstorm \$ Flood Hazard Maps and damage risk of Housing, Ministry of Urban Affairs \& Employment, Government of India, 1997

[2]. www.census2011.co.in

[3]. www.google.com website (Accessed from 1, march.2014 to 12, april.2014). 